\title{
Pengaruh LDR, NPL, CAR dan DPK terhadap ROA pada Perusahaan Perbankan Periode 2015-2019
}

\author{
Shri Aswini ${ }^{1}$, Erika Gunawan ${ }^{2 *}$, Kevin Chaniago ${ }^{3}$, Fuji Astuti ${ }^{4}$ \\ Fakultas Ekonomi Universitas Prima Indonesia, Medan ${ }^{1234}$ \\ sriaswini14@gmail.com, kunawanerika99@gmail.com, kevchinan97@ gmail.com, \\ fujiastuty424@gmail.com
}

*Corresponding Author

Submitted: January, 27, 2021

Accepted: February, 32021

Published: February, 21, 2021

\begin{abstract}
This slowing economy resulted in disrupted banking activities, especially profits decreased. The purpose of this study was to determine the effect of the Loan to Deposit Ratio, Non Performing Loans, Capital Adequacy Ratio, and Third Party Funds on Return on Assets in Banking Companies on the Indonesia Stock Exchange 2015-2019 Period either partially or simultaneously. This research approach is quantitative. This type of research is descriptive statistics. The nature of this research is explanatory research. The population in this study was 45 banking companies on the Indonesia Stock Exchange for the 2015-2019 period. Technique sampling for this research used purposive sampling. So this research sample was 23 banking companies using the Multiple linear regression model. The result is that the Loan to Deposit Ratio has no effect on Return on Assets in Banking Companies on the Indonesia Stock Exchange for the 2015-2019 Period. Non-Performing Loans have anegative effect on Return on Assets in Banking Companies on the Indonesia Stock Exchange for the 2015-2019 Period. Capital Adequacy Ratio has a positive effect on Return on Assets in Banking Companies on the Indonesia Stock Exchange 2015-2019 Period. Third Party Funds have no effect on Return on Assets in Banking Companies on the Indonesia Stock Exchange for the 2015-2019 Period. Together Loan to Deposit Ratio, Non Performing Loans, Capital Adequacy Ratio and Third Party Funds have an effect on Return on Assets in Banking Companies on the Indonesia Stock Exchange 2015-2019 Period. The magnitude of this influence is $25.4 \%$ where the remaining $74.6 \%$ is influenced by other independent variables for example the ratio of income to operating expenses.
\end{abstract}

Keywords: Capital Adequacy Ratio, Loan to Deposit Ratio, Non-Performing Loan,Return on Assets and Third Party Funds

\section{PENDAHULUAN}

Tahun 2015 terjadi perlambatan ekonomi global dan adanya perkembangan ekonomi domestik menyebabkan penurunan pertumbuhan ekonomi, harga komoditas dan nilai tukar juga berdampak pada industri keuangan. Salah satu perusahaan yang terkena dampak resesi adalah bank. Meski otoritas jasa keuangan (OJK) menilai sektor bankmemperlihatkan kinerja yang baik meskipun terjadi perlambatan ekonomi. Berdasarkan data OJK November 2015, aset tumbuh $929 \%$ setiap tahun, kredit tumbuh 9,85\%, dana pihak ketiga tumbuh 7,7\% (Gischa, 2020).

Perlambatan ekonomi telah menyebabkan terganggunya operasional perbankan terutama laba. Metode pengukuran keuntungan bankdisebut return on asset. Manajemen bank perlu menjaga besarnya Return on assets (ROA) tahunan yang dimiliki bank. Semakin tinggi Return on assets (ROA) bank, semakin baik pengaruhnya. Informasi keuangan pada Return on assets (ROA) mengalami peningkatan dari tahun ke tahun dapat menunjukkan stabilitas perusahaan(Harun, 2016). Adapun beberapa faktor mempengaruhi ROA adalah Loan to Deposit Ratio, Non Performing Loan, Capital Adequacy Ratio dan Dana Pihak Ketiga. 
Salah satu aspek pengaruhi Return on assets (ROA) besar merupakan Loan to endapan ratio yang besar. Bila nilai perbandingan Hubungan jarak jauh terletak dibawah $78 \%$ hingga bisa dibilang kalau bank itu tidak bisa menuangkan kembali dengan bagus semua anggaran yang sudah dikumpulkan. Bila perbandingan Hubungan jarak jauh bank menggapai lebih dari $92 \%$ hingga keseluruhan angsuran yang disalurkan oleh bank itu sudah melampaui anggaran yang dikumpulkan (Atmoko, et. al., 2018).

Hubungan jarak jauh yang besar pula pengaruhi permasalahan angsuran macet yang jadi penghalang kenaikan keuntungan industri. Non Performing Loan memantulkan resiko angsuran, alhasil terus menjadi kecil Non Performing Loan terus menjadi kecil resiko angsuran yang dijamin bank. Bank Indonesia sudah memutuskan standar perbandingan Non Performing Loan bersih yang bagus sepatutnya kurang dari 5\%. Terus menjadi besar Non Performing Loan, terus menjadi kecil Return on assets sebab pemasukan bunga bermasalah(Priatna, 2019).

Angsuran macet berikan akibat yang lumayan besar kepada investasi bank. Return on assets (ROA) besar membuktikan bank mempunyai Capital Adequacy Ratio yang besar dimana peninggalan yang dipunyai perbankan itu besar. Perbankan wajib bisa penuhi standar berkecukupan modalnya buat menjamin terhindarnya dari resiko yang bisa jadi mencuat dalam melaksanakan aktivitas upaya. Bila bank mempunyai modal yang lumayan, hingga bank mempunyai pangkal energi keuangan yang lumayan buat berawas-awas kepada kemampuan kehilangan. Bila berkecukupan modal (Capital Adequacy Ratio) telah bisa terkabul hingga hendak sanggup tingkatkan keahlian bank dalam kenaikan keuntungan (Natasia, 2015).

Investasi perbankan pula dipengaruhi oleh anggaran pihak ketiga yang terdapat. Anggaran pihak ketiga membuktikan tingkatan dana pelanggan di sesuatu bank. Bertumbuhnya Anggaran Pihak Ketiga yang besar hingga pemberian angsuran hendak berkembang besar, alhasil aktivitas agregasi serta distribusi anggaran oleh bank biasa bisa berhasil dengan bagus. Kasus yang kerap terjalin pada Anggaran Pihak Ketiga ialah ketidakstabilan antara anggaran yang terdapat dengan anggaran yang disalurkan menyebabkan Return on assets (ROA) jadi tidak normal juga(Asriningrum, 2019).

Penelitian ini merupakan kelanjutannya dari penelitian (Hartanti, 2017) yang menunjukkan jika secara parsial NPL berpengaruh negatif terhadap ROA, sedangkan LDR tidak berpengaruh terhadap ROA.Sedangkan berbeda dengan hasil penelitian (Piliang, 2019) yang menemukan jika NPL tidak memiliki pengaruh terhadap ROA namun LDR yang berpengaruh secara positif dan signifikan terhadap ROA.Dengan adanya research gap tersebutlah yang melatarbelakangi diadakannya penelitian ini dengan menambahkan variabel CAR dan DPK.

\section{STUDI LITERATUR}

\section{Dampak Loan To Deposit Ratio pada Return On Asset}

Kegiatan utama bank adalah menghimpun dana, dapat dikatakan jika jumlah pinjaman bertambah, maka justru akan menambah keuntungan perusahaan. Begitu pula sebaliknya, jika kredit tidak bisa dialokasikan maka bank akan rugi karena harus membayar simpanannya (Kasmir, 2016).

Perbandingan pinjaman kepada endapan bertambah buat seluruh bank. Perbandingan yang lebih besar ini bisa dipaparkan beberapa oleh kemampuan serta kemauan bank buat menanggulangi perkara likuiditasnya memakai manajemen kepekaan serta bukannya sekedar menggantungkan diri pada adaptasi peninggalan serta beberapa yang lain lewat upaya bank buat mendapatkan tingkatan pemasukan yang lebih besar (Darmawi, 2014).

Pemberian angsuran yang besar bisa menciptakan profit yang besar pula. Dengan beranggapan sejenis itu, para banker bisa kurang ingat dengan membenarkan permohonan pinjaman paling-paling tanpa mencermati jumlah anggaran yang bisa digabungkan (latumaerissa, 2018).

\section{Dampak Non Performing Loan pada Return on Asset}

Pihak bank cenderung menggunakan bank sebagai sumber pembiayaan untuk usahanya sendiri atau kelompok atau pihak yang terkait dengan berbagai proyek agar lolos review Bank 
Indonesia. Akibatnya bank mengandalkan kinerja debitur tertentu, yang selanjutnya dapat menjadi penyebab pembengkakan pada NPL yang akan menimbulkan risiko likuiditas (Sudirman, 2013).

NPL yang tinggi hendak menimbulkan tingginya bayaran modal(cost of capital) yang terlihat dari bayaran operasional dari untuk bank biasa yang berhubungan. Dengan tingginya bayaran modal hingga hendak berdampakpada perolehan laba bersih dari bank (Latumaerissa, 2014).

\section{Dampak Capital Adequacy Ratio pada Return on Asset}

Modal ialah aspek yang amat berarti untuk kemajuan serta perkembangan bank sekalian melindungi keyakinan warga. Tiap invensi aktiva, di sisi berpotensi menciptakan profit pula berpotensi memunculkan terbentuknya resiko. Oleh sebab itu, modal pula wajib bisa dipakai buat melindungi mungkin terbentuknya resiko kehilangan atas pemodalan pada aktiva, paling utama yang berawal dari dana- dana pihak ketiga ataupun warga. Kenaikan kedudukan aktiva selaku penghasil profit wajib dengan cara simultan dibarengi dengan estimasi resiko yang bisa jadi mencuat untuk mencegah kebutuhan para owner anggaran (Muhamad, 2014).

\section{Dampak Dana Pihak Ketiga pada Return On Asset}

Dana dikumpulkan dari warga memiliki akibat terbanyak dari sebagian pangkal anggaran setelah itu disalurkan kembali pada warga dalam wujud angsuran. Terus menjadi besar anggaran pihak ketiga disalurkan ke dalam wujud angsuran, hingga terus menjadi besar likuiditas bank (Edo dan Wiagustini, 2014).

\section{METODE}

Pendekatan penelitian ini kuantitatif yang diperoleh dari data sekunder berupa laporan keuangan tahunan yang telah diaudit. Jenis penelitian ini statiska deskriptif yang menjelaskan setiap statistik yang telah diolah. Sedangkan sifat penelitian ini adalah eksplanasi. Dimana dalam hal ini peneliti akan berusaha membahas hasil penelitian yang diperoleh dengan membandingkan hasil penelitian ini dengan hasil peneliti sebelumnya.

\section{Populasi dan Sampel}

Populasi dalam penelitian ini adalah 45 perusahaan perbankan di Bursa Efek Indonesia Periode 2015-2019.

Penarikan sampel dilakukan dengan purposive sampling method.

Tabel 1Sampel Penelitian

\begin{tabular}{|c|l|c|}
\hline No. & \multicolumn{1}{|c|}{ Kriteria } & JumlahSampel \\
\hline 1. & $\begin{array}{l}\text { Industri Perbankan yang sudah go khalayak serta didaftarkan di } \\
\text { Pasar uang Dampak Indonesia Rentang waktu 2015- 2019 }\end{array}$ & 45 \\
\hline 2 & $\begin{array}{l}\text { Industri Perbankan yang tidak mempublikasikan informasi } \\
\text { keuangannya dengan cara beruntun sepanjang Rentang waktu } \\
2015-2019\end{array}$ & $(8)$ \\
\hline 3 & $\begin{array}{l}\text { Industri Perbankan yang hadapi kehilangan Rentang waktu 2015- } \\
2019 \quad \text { JumlahSampel Perusahaan }\end{array}$ & $\mathbf{2 3}$ \\
\hline \multicolumn{2}{|c|}{ Total Sampel (5 x 23) } \\
\hline
\end{tabular}

Sumber : Data Diolah, 2020

\section{Definisi Operasional}

\section{Loan to Deposit Ratio $\left(\mathrm{X}_{1}\right)$}

Loan Deposit Ratio (LDR) untuk menunjukkan kesehatan bank dalam memberikan pembiayaan (Muhamad, 2014). 
Non Performing Loan $\left(\mathrm{X}_{2}\right)$

$$
\text { LDR }=\frac{\text { Total Pembiayaan }}{\text { Total Dana Pihak Ketiga }}
$$

NPL merupakan salah satu indikator dalam menilai tingkat kesehatan bank umum (Latumaerissa, 2014).

Capital adequacy ratio $\left(\mathrm{X}_{3}\right)$

$$
\text { NPL }=\frac{\text { Kredit Bermasalah }}{\text { TotalKredit }}
$$

Capital adequacy ratio (CAR) ataupun kerap diucap dengan sebutan perbandingan berkecukupan modal bank, ialah gimana suatu perbankan sanggup membantu kegiatan kegiatannya dengan kepemilikan modal yang dipunyanya (Mainata dan Ardiani, 2017).

$$
\mathrm{CAR}=\frac{\text { Modal Bank }}{\text { Aktiva Tertimbang Menurut Risiko }} \times 100 \%
$$

Dana Pihak Ketiga $\left(\mathrm{X}_{4}\right)$

Dana pihak ketiga dimiliki oleh bank dan berasal dari pihak eksternalatau masyarakat, tujuannya untuk menyimpan sebagian dari aset / dananya dibank untuk memastikan keamanannya dan menariknya ketika masyarakat sebagai nasabah membutuhkannya. (Afrizal, 2017).

$$
\text { Dana Pihak Ketiga }=\frac{\text { Total DPK }}{\text { Total DPK }+ \text { Modal }} \times 100 \%
$$

Return on assets (Y)

Return on assetmerupakan perbandingan yang melukiskan keahlian bank dalam mengatur anggaran yang diinvestasikan dalam totalitas peninggalan atau harta yang menciptakan profit(Muhamad, 2014).

$$
\mathrm{ROA}=\frac{\text { Laba }}{\text { Total Aktiva }}
$$

\section{Teknik Analisis Data}

Metode analisa informasi kuantitatif dengan memakai dorongan SPSS dalam mengatur informasi riset. Saat sebelum melaksanakan pengerjaan informasi anggapan terlebih dulu memakai percobaan anggapan klasik. Dalam percobaan anggapan klasik ini melingkupi percobaan normalitas, percobaan multikolineritas, percobaan autokorelasi serta percobaan heterokedastisitas. Analisa regresi linear berganda membuktikan elastis riset ini lebih dari satu elastis bebas dengan pertemuan selaku berikut:

\section{Keterangan :}

$$
\mathrm{Y}=\mathrm{a}+\mathrm{b}_{1} \mathrm{X}_{1}+\mathrm{b}_{2} \mathrm{X}_{2}+\mathrm{b}_{3} \mathrm{X}_{3}+\mathrm{b}_{4} \mathrm{X}_{4}+\mathrm{e}
$$

Y : Penyaluran Kredit

a : konstanta

$\mathrm{X}_{1} \quad$ : Dana Pihak Ketiga

$\mathrm{X}_{2} \quad$ :Capital Adequacy Ratio

$\mathrm{X}_{3} \quad$ :Non Performing Loan

$\mathrm{X}_{4} \quad$ :Suku Bunga

$\mathrm{b}_{1,2,3,4}$ : besaran koefisien regresi dari masing-masing variabel

e : error

Pengujian hipotesis yang dilakukan pengujian secara parsial (uji t), pengujian secara simultan (uji F) dan koefisien determinasi $\left(\mathrm{R}^{2}\right)$. 
HASIL

Analisa regresi linear berganda dipakai buat memperkirakan pergantian(naik serta turunnya) elastis terbatas yang dipaparkan oleh 3 elastis bebas. Hasil analisa regresi berganda pada bentuk regresi yang hendak dicoba ditunjukkan pada bagan 2 selanjutnya.

Tabel 2. Hasil Analisis Regresi Linier Berganda

Coefficients $^{\mathrm{a}}$

\begin{tabular}{|l|l|r|r|r|}
\hline \multirow{2}{*}{ Model } & \multicolumn{2}{|c|}{ Unstandardized Coefficients } & Standardized Coefficients \\
\cline { 2 - 5 } & \multicolumn{1}{l|}{ B } & Std. Error & \multicolumn{2}{c|}{ Beta } \\
\hline \multirow{3}{*}{1 (Constant) } & 1.663 & 2.541 & -.018 \\
\cline { 2 - 5 } & LDR & -.001 & .006 & -.173 \\
\cline { 2 - 5 } NPL & -.144 & .068 & .434 \\
\cline { 2 - 5 } CAR & .089 & .024 & -.086 \\
\cline { 2 - 5 } & DPK & -.016 & .023 & \\
\hline
\end{tabular}

a. Dependent Variable: ROA

Sumber : Hasil Pengolahan Data, 2020

ROA $=1,663+0,008$ LDR - 0,027 NPL + 0,091 CAR - 0,009 DPK

Koefisien Determinasi $\left(\mathbf{R}^{2}\right)$

Koefisien determinasi mengukur seberapa kemampuan variabel bebas dapat menjelaskan variabel terikatnya.

Tabel 3. Koefisien Determinasi

\begin{tabular}{|l|c|r|r|}
\multicolumn{4}{c}{ Model Summary } \\
\hline Model & \multicolumn{1}{c|}{ R } & R Square & Adjusted R Square \\
\hline 1 & $.529^{\mathrm{a}}$ & .280 & .254 \\
\hline
\end{tabular}

a. Predictors: (Constant), DPK, NPL, LDR, CAR

b. Dependent Variable: ROA

Sumber : Hasil Pengolahan Data, 2020

Adjusted $R$ Square-nya 0,254 dengan pengaruh 25,4\% terhadap Return on Asset dan sisanya $74,6 \%$ dipengaruhi variabel lainnya.

\section{Pengujian Hipotesis Secara Simultan (Uji Statistik F)}

Uji $\mathrm{F}$ digunakan untuk menguji apakah variabel independen secara bersama-sama mempengaruhi variabel dependen.

Tabel 4. Hasil Uji Statistik F

ANOVA $^{\mathrm{a}}$

\begin{tabular}{|l|l|r|r|r|r|}
\hline \multicolumn{2}{|l|}{ Model } & \multicolumn{1}{c|}{ df } & Mean Square & F & Sig. \\
\hline \multirow{3}{*}{1} & Regression & 4 & 7.606 & 10.704 & $.000^{\mathrm{b}}$ \\
\cline { 2 - 6 } & Residual & 110 & .711 & & \\
\cline { 2 - 6 } & Total & 114 & & & \\
\hline
\end{tabular}

a. Dependent Variable: ROA

b. Predictors: (Constant), DPK, NPL, LDR, CAR

Sumber : Hasil Pengolahan Data, 2020

$\mathrm{F}_{\text {hitung }}=10,704$, sig $=0,000$ dan $\mathrm{F}_{\text {tabel }}(115-5=110)=2,45 . \quad \mathrm{F}_{\text {hitung }}>\mathrm{F}_{\text {tabel }}$ yaitu 10,704>2,45terlihat $\mathrm{H}_{0}$ ditolak, $\mathrm{H}_{\mathrm{a}}$ diterima ditunjukkan Loan to Deposit Ratio, Non Performing Loan, Capital Adequacy Ratio dan Dana Pihak Ketiga berpengaruh terhadap Return on Assets Pada Perusahaan Perbankan di Bursa Efek Indonesia Periode 2015-2019. 


\section{Pengujian Hipotesis Secara Parsial (Uji Statistik t)} dependen.

Uji t menguji apakah variabel independen secara individual mempengaruhi variabel

Tabel 5.Hasil Uji Statistik t

Coefficients $^{\mathbf{a}}$

Sumber : Hasil Pengolahan Data, 2020

\begin{tabular}{|l|l|r|r|}
\hline \multicolumn{2}{|l|}{} & & \\
\multicolumn{2}{|l|}{ Model } & \multicolumn{1}{c|}{$\mathrm{t}$} & Sig. \\
\hline \multirow{2}{*}{1} & (Constant) & .655 & .514 \\
\cline { 2 - 5 } & LDR & -.199 & .843 \\
\cline { 2 - 5 } & NPL & -2.101 & .038 \\
\cline { 2 - 5 } CAR & 3.730 & .000 \\
\cline { 2 - 4 } & DPK & -.701 & .485 \\
\hline
\end{tabular}

a. Dependent Variable: ROA

1. Loan to Deposit Ratiot $\mathrm{t}_{\text {hitung }}=-0,199$, sig $=0,843$, $\mathrm{t}_{\text {tabel }}(115-4=111)=1,981$, $-\mathrm{t}_{\text {hitung }}>-\mathrm{t}_{\text {tabel, }}-$ 0,199 > -1,981 $\mathrm{H}_{0}$ ditolak, $\mathrm{H}_{2}$ diterima ditunjukkan Loan to Deposit Ratio tidak mempengaruhi Return on Assets Pada Perusahaan Perbankan di Bursa Efek Indonesia Periode 2015-2019.

2. Non Performing Loant $\mathrm{t}_{\mathrm{itung}}=-2,101$, sig $=0,038, \mathrm{t}_{\text {tabel }}(115-4=111)=1,981 \quad-\mathrm{t}_{\mathrm{hitung}}<-\mathrm{t}_{\text {tabel, }}$ $2,101<-1,981 \mathrm{H}_{0}$ diterima, $\mathrm{H}_{\mathrm{a}}$ ditolak ditunjukkan Non Performing Loan berpengaruh terhadap Return on Assets Pada Perusahaan Perbankan di Bursa Efek Indonesia Periode 20152019.

3. Capital Adequacy Ratio $\mathrm{t}_{\text {hitung }}=3,730$, sig $=0,000, \mathrm{t}_{\text {tabel }}(115-4=111)=1,981, \quad \mathrm{t}_{\text {hitung }}>\mathrm{t}_{\text {tabel, }}$, 3,730>1,981 $\mathrm{H}_{0}$ ditolak, $\mathrm{H}_{\mathrm{a}}$ diterima ditunjukkan Capital Adequacy Ratio memiliki pengaruh Return on Assets Pada Perusahaan Perbankan di Bursa Efek Indonesia Periode 2015-2019.

4. Dana Pihak Ketigat ${ }_{\text {hitung }}=-0,701$, sig $=0,485$, $\mathrm{t}_{\text {tabel }}(115-4=111)=1,981$, $-\mathrm{t}_{\text {hitung }}>-\mathrm{t}_{\text {tabel, }}-0,701$ $>-1,981 \mathrm{H}_{0}$ ditolak, $\mathrm{H}_{\mathrm{a}}$ diterima ditunjukkan Dana Pihak Ketiga tidak berpengaruh terhadap Return on Assets Pada Perusahaan Perbankan di Bursa Efek Indonesia Periode 2015-2019.

\section{PEMBAHASAN}

\section{Loan To Deposit Ratio Pengaruhnya pada Return On Asset}

Hasil pengetesan ini merupakan Loan to Endapan Ratio tidak mempengaruhi kepada Return on Assets Pada Industri Perbankan di Pasar uang Dampak Indonesia Rentang waktu 20152019. Sedemikian itu pula hasil riset( Hantono, 2017) yang membuktikan tidak terdapat akibat Hubungan jarak jauh kepada ROA. Hasil riset tidak tidak berubah- ubah dengan filosofi(Kasmir, 2016), Aktivitas penting bank merupakan menuangkan anggaran, hingga alami dibilang kalau bila jumlah pinjaman bertambah, hingga dalam praktiknya hendak sanggup tingkatkan keuntungan industri. Begitu pula kebalikannya bila tidak sanggup menuangkan angsuran, hingga bank hendak cedera sebab bobot bayaran buat penyimpanan anggaran senantiasa wajib dibayar.

\section{Non Performing Loan Pengaruhnya pada Return on Asset}

Hasil riset ini merupakan Non Performing Loan mempengaruhi kepada Return on Assets Pada Industri Perbankan di Pasar uang Dampak Indonesia Rentang waktu 2015- 2019. Searah pula dengan hasil riset (Peling, 2018) yang membuktikan NPL pula mempengaruhi penting dengan cara minus kepada ROA. Hasil riset ini tidak tidak berubah- ubah dengan filosofi(Sudirman, 2013) para owner bank mengarah memakai bank selaku pangkal pembiayaan usahanya sendiri ataupun kelompoknya ataupun pihak yang terpaut dengan bermacam rekayasa buat celus dari pengecekan Bank Indonesia. Aksi itu bawa akibat kalau bank terkait pada kemampuan debitur khusus yang setelah itu nyatanya ialah pemicu membengkaknya NPL alhasil menimbulkan tampaknya resiko likuiditas. 


\section{Capital Adequacy RatioPengaruhnya pada Return on Asset}

Hasil pengujian ini adalah Capital Adequacy Ratio berpengaruh terhadap Return on Assets Pada Perusahaan Perbankan di Bursa Efek Indonesia Periode 2015-2019.Namun tidak sejalan dengan hasil penelitian (Hantono, 2019) yang menemukan CAR tidak berpengaruh pada ROA perusahaan perbankan. Hasil penelitian ini konsisten dengan teori (Muhamad, 2014) permodalan menjadi faktor penting dalam menjaga perkembangan dan kemajuan bank yang dipercaya oleh masyarakat. Penciptaan setiap aset berpotensi menimbulkan risiko selain berpotensi menghasilkan keuntungan. Oleh karena itu, modal juga harus digunakan untuk melindungi investasi aset, terutama risiko kerugian investasi aset dari pihak ketiga atau dana masyarakat. Selain meningkatkan peran aset sebagai penghasil keuntungan, kita juga harus mempertimbangkan kemungkinan risiko untuk melindungi kepentingan pemilik dana.

\section{Pengaruh Dana Pihak Ketiga Terhadap Return On Asset}

Hasil pengujian ini adalah Dana Pihak Ketiga tidak berpengaruh terhadap Return on Assets Pada Perusahaan Perbankan di Bursa Efek Indonesia Periode 2015-2019.Sejalan dengan penelitian (Husaeni, 2017) yang menunjukkan dana pihak ketiga juga tidak mempengaruhi ROA namun beda dengan hasil uji (Katuuk, Kumaat dan Niode, 2018). Hasil penelitian ini tidak konsisten dengan teori (Edo dan Wiagustini, 2014) dana yang terkumpul dari masyarakat berasal dari berbagai sumber pendanaan, yang memberikan kontribusi paling besar kemudian mengalir kembali ke masyarakat dalam bentuk kredit. Semakin besar jumlah dana pihak ketiga yang digunakan untuk kredit, semakin tinggi likuiditas bank tersebut.

\section{KESIMPULAN}

Bersumber pada hasil riset bisa ditarik kesimpulan selaku selanjutnya: Dengan cara parsial Loan to Endapan Ratio serta anggaran pihak ketiga tidak mempengaruhi serta tidak penting kepada Return on Assets Pada Industri Perbankan di Pasar uang Dampak Indonesia Rentang waktu 20152019 tetapi Non Performing Loan mempengaruhi dengan cara penting dengan arah minus kepada Return on Assets Pada Industri Perbankan di Pasar uang Dampak Indonesia Rentang waktu 20152019 sebaliknya Capital Adequacy Ratio mempengaruhi dengan cara penting dengan arah positif kepada Return on Assets Pada Industri Perbankan di Pasar uang Dampak Indonesia Rentang waktu 2015- 2019. Dengan cara simultan keempat elastis bebas Loan to Endapan Ratio, Non Performing Loan, Capital Adequacy Ratio serta Anggaran Pihak Ketiga dengan cara berbarengan mempengaruhi penting kepada Return on Assets Pada Industri Perbankan di Pasar uang Dampak Indonesia Rentang waktu 2015-2019.

\section{REFERENSI}

Afrizal. (2017). Pengaruh Dana Pihak Ketiga, Quick Ratio, Current Asset dan Non Performing Performance Finance terhadap Profitabilitas PT. Bank Syariah Mandiri Indonesia. Jurnal Valuta Universitas Islam Riau, 3 No. 1, 189-210.

Asriningrum, C. (2019). Analisis Pengaruh NPF, DPK, dan ROA terhadap Market Share Bank Syariah di Indonesia (Studi Kasus pada Bank Umum Syariah periode 2014-2018). Skripsi Fakultas Ekonomi dan Bisnis Islam IAIN Purwokerto.

Atmoko, A. S., Amboningtyas, D., \& Fathoni, A. (2018). Effect of LDR, NPL and BOPO on Profitabilities Based on Banking Companies Listed on the Indonesia Stock Exchange. Journal of Management, 4 No. 4.

Darmawi, H. (2014). Manajemen Perbankan. Jakarta: Bumi Aksara.

Dewi, N. V. (2019). Faktor-Faktor yang Mempengaruhi Profitabilitas Perbankan (Studi Kasus pada Bank Umum yang Terdaftar di Bursa Efek Indonesia periode 2015-2017). Jurnal Ilmu Manajemen, 4 No. 2, 223-237.

Edo, D., \& Wiagustini. (2014). Pengaruh Dana Pihak Ketiga, Non Performing Loan dan Capital Adequacy Ratio terhadap Loan Deposit Ratio dan Return on Assets pada Sektor Perbankan 
di Bursa Efek Indonesia. e-Jurnal Ekonomi dan Bisnis Universitas Udayana, 3 No. 11, 650-673.

Gischa, S. (2020, Agustus). kompas.com. Retrieved from https://www.kompas.com/skola/read/2020/08/04/150000069/dampak-resesi-ekonomi

Hantono. (2017, January). Effect of Capital Adequacy Ratio (CAR), Loan to Deposit Ratio (LDR) and Non Performing Loan (NPL) to Return on Assets (ROA) Listed in Banking in Indonesia Stock Exchange. International Journal of Education and Research, 5 No. l(ISSN : 2411-5681), 69-80.

Hantono. (2019, April). Pengaruh Rasio Kecukupan Modal, Loan to Deposit Ratio, Besaran Perusahaan dan Current Ratio terhadap Return on Assets Perusahaan Perbankan terdaftar di BEI Periode 2012-2016. Profita : Komunikasi Ilmiah Akuntansi dan Perpajakan, 12 No. I(e-ISSN : 2622-1950), 80-93.

Hartanti. (2017). Analisis NPL dan LDR terhadap ROA pada PT. Bank Mandiri Tbk, PT. Bank Nasional Indonesia Tbk dan PT Bank Rakyat Indonesia Tbk. Jurnal Moneter, IV. No. 1.

Harun, U. (2016). Pengaruh Ratio-Ratio Keuangan CAR, LDR, NIM, BOPO, NPL terhadap ROA. Jurnal Riset Bisnis dan Manajemen, 4 No. 1, 67-82.

Husaeni, U. A. (2017). Analisis Pengaruh Dana PIhak KEtiga dan Non Performing Financing terhadap Return on Asset Pada BPRS di Indonesia. Jurnal Ekonomi Syariah, 1-16.

Kasmir. (2016). Analisis Laporan Keuangan. Jakarta: Raja Grafindo Persada.

Katuuk, P. M., Kumaat, R. J., \& Niode, A. O. (2018). Pengaruh Dana Pihak Ketiga, Loan to Deposit Ratio, Biaya Operasional Pendapatan Operasional terhadap Return on Asset Bank Umum di Indonesia periode 2010.1-2017.4. Jurnal Berkala Ilmiah Efisiensi, 170-180.

Latumaerissa, J. (2018). Manajemen Bank Umum. Jakarta: Mitra Wacana Media.

Mainata, D., \& Ardiani, A. F. (2017). Pengaruh Capital Adequacy Ratio (CAR) terhadap Return on Aset (ROA) pada Bank Syariah. Jurnal Ekonomi dan Bisnis ISlam, 3 No. 1.

Muhamad. (2014). Manajemen Dana Bank Syariah. Jakarta: RajaGrafindo Persada.

Natasia, R. (2015). Pengaruh Risiko Kredit, Profitabilitas, Likuiditas dan Efisiensi Usaha terhadap Kecukupan Modal pada Bank yang Terdaftar di Bursa Efek Indonesia periode 2010-2014. Jurnal Akuntansi AKUNESA, 3 No. 3, 1-24.

Peling, I. (2018). Pengaruh LDR, NPL dan BOPO terhadap Profitabilitas pada PT. BPD Bali Periode tahun 2009-2016. e-Jurnal Manajemen Unud, 2999-3026.

Piliang, B. V. (2019). Pengaruh Non Performing Loan (NPL) dan Loan to Deposit Ratio (LDR) terhadap Return on Assets (ROA) pada Bank Umum Swasta Devisa yang terdaftar di Bursa Efek Indonesia (BEI) periode 2012-2016. Jurnal Universitas Langlang Buana, 3 No. 2.

Priatna, H. (2019). Non Performing Loan (NPL) sebagar Resiko Bank atas Pemberian Kredit. Jurnal Ilmiah Akuntansi FE Unibba, 8 No. 1.

Sudirman, I. W. (2013). Manajemen Perbankan Menuju Bankir Konvensional yang Profesional. Jakarta: Kencana. 